FACTA UNIVERSITATIS

Series: Economics and Organization Vol. 18, No 3, 2021, pp. 289 - 298

https://doi.org/10.22190/FUEO210611020S

Original Scientific Paper

\title{
THE IMPACT OF THE PANDEMIC COVID-19 ON HOSPITALITY INDUSTRY AND TOURISM WORKERS
}

UDC 338.48:[616.98:578.834

Dana-Maria Stoicea (Ignătescu)

University of Craiova, Doctoral School of Economics, Craiova, Romania

ORCID iD: Dana-Maria Stoicea (Ignătescu) N/A

\begin{abstract}
The contemporary Coronavirus pandemic (Covid-19) has led the world to a severe socio-economic crisis and psychological distress. It has distressed the economy, but the services sector, especially the hospitality industry, is seriously affected by it This study investigates how this virus influences organizational confidence, job satisfaction, and increases employees' sense of insecurity and perceptions of being unemployed. We performed a comparative analysis of the main indicators in tourism in 2020 compared to the same period of 2019, referring to the data recorded internationally. Also, the research aimed to identify how much the hospitality sector is affected by the crisis produced by the Covid-19 pandemic. The results specify that perceived job insecurity interposes the fear of the economic crisis.
\end{abstract}

Key words: Covid-19 fear, perceived job insecurity, hospitality industry, unemployment

JEL Classification: Z3, L83, L88.

\section{INTRODUCTION}

The COVID-19 pandemic crisis "has severely impacted the good health and wellbeing of people around the world. On these unforeseen challenges, decision makers reconfigure advanced resilient policies and strategies for the labor markets" (Cristea et al., 2020). "The world is always facing challenges due to technological advances, natural disasters and demographic factors. However, coronavirus has emerged as the biggest challenge of the decade" (Khan et al., 2021).

Received June 11, 2021 / Revised July 02, 2021 / Accepted July 05, 2021

Corresponding author: Dana-Maria Stoicea (Ignătescu)

University of Craiova, Faculty of Economics and Business Administration, 13, A.I. Cuza Street, Craiova, 200585, Romania |E-mail: danaignatescu@gmail.com 
"Covid-19, believed to be from Wuhan, China, has infected more than 136 million people in 188 countries and killed more than 2,900,000" (Kang et al., 2021). They mentioned that, "taking into consideration the relatively high mortality of Covid-19 in comparison to other influenza-like diseases and the ease of its human-to-human transmission, the World Health Organisation has labeled Covid-19 a pandemic". "A lot of countries have declared a temporary suspension of public / private outdoor activities and closed down key businesses" (Kang et al., 2021). "Tourism, as a global spread of viruses" (Browne et al., 2016) "was one of the first industries directly affected by global pandemic measures" (Nicola et al., 2020). Covid-19 is not as contagious as measles, nor as likely to kill a person as Ebola, but people can be contagious a few days before symptoms (Bai et al., 2020).

A global recession, economic recessions and declining industry performance are "just some of the consequences of this global emergency" (Khan et al., 2021). "Prudential regulations in the financial area are needed in order to provide solutions for the cyclical side of this systemic risk, and could also limit the possibility of over-liquidity builtup" (Tănasie, 2011). The growing number of cases "created panic, stress and nervousness among people, then they had to face psychological problems, panic attacks and the understanding that there is no known cure for this disease" (Ahorsu et al., 2020).

Škare (2021) said that, "since the beginning of the Covid-19 crisis in China, the impact of the pandemic on the travel tourism industry has been significantly underestimated". Even now, "the decision political factors and practitioners from the tourism sector do not have a full understanding of the scenarios and effects of the crisis, that will have an unprecedented impact on the tourism industry" (Škare et al., 2021). "Between the problems that may occur in conection with the tourism stakeholders we can mention distrust for the government or insufficient support of the government, inclusion of politics, too much administration or bureaucracy" (Ionescu et al., 2019), exceeding influence of the essential interest and influential groups, "insufficient inclusion of individual interest groups, insufficient awareness on the need to participate, lack of guidance and wrongly defined priorities goals and conduction strategies" (Ionescu et al., 2019).

Previous studies have considered that the fear of loosing jobs and the financial insecurity, as being the most substantial cosequences of the gouvernmental politics. In the private sector, "the fear of job insecurity is a permanent threat, but it has nevertheless gained more attention during this pandemic. The fear of being fired from the ongoing jobs is greater than being infected" (Khan et al., 2021).

According to World Travel and Tourism Council (WTTC, 2020), "over 50 million jobs related to tourism/hospitality are currently at risk". While many services for example administration, education, training, and libraries can be administered from home, most staff in sales-related industries cannot operate remotely, (for example flight attendants, reception workers, etc). "WTTC also estimates daily loss of one million jobs in the travel tourism sector due to the widespread impact of the coronavirus pandemic" (Škare et al., 2021).

To date, the research "has focused on the high levels of depression, anxiety, insomnia and stress related symptoms of the workers in the health department during the current pandemic" (Pappa et al., 2020), but "few studies have taken into consideration the welfare of tourism and hospitality, of the affiliated staff and their concerns at work" (Kang et al., 2021). Because this field is under-researched, this study seeks to "fill the gap and open new horizons for managers" (Khan et al., 2021). Specifically, in this research we investigate "how perceived job insecurity meditates on the relationship between fear of economic crisis, unemployment, and mental health" (Khan et al., 2021). 
The main goal of the research is to add to the literature of the hospitality sector, as it is a sector that has received little attention from researchers, and furthermore it is a sector that is confronting significant repercussions through this pandemic. In the first part of the paper we approached the theoretical aspects of the literature, and in the second part we made a presentation of the research methodology. The results highlighted the fact that an extremely large number of people around the world lost their jobs due to the coronavirus pandemic, and the incomes of those in the hospitality sector have considerably decreased in 2020, compared to 2019.

\section{LITERATURE REVIEW}

Firoiu and the contributors (2019) mention that "the tourism sector is considered to be a very important field for the global economy and tourism is an essential growth and prosperity factor for all areas, generated positive, direct and indirect effects on the local and regional economy". "With a strong dynamic and a high share of the contribution to the global GDP, tourism generates unlimited development opportunities, but also the freedom to travel, therefore being an open system, with extraordinary benefits for society, economy and environment" (Firoiu et al., 2019). Tănasie and Fratoștițeanu (2009) said that the "tourism is an essential component for both economic development and poverty reduction in developing countries".

"In this sector, the part time jobs are preferred in a greater extent than in others and there are applied flexible methods to the work force employment (the hiring during the week-end, on the occasion of certain events, holidays or for certain activities-guides, instructors,etc)" (Gruescu et al., 2009).

$\mathrm{Hu}$ (2021) mentioned that "Covid-19 pandemics affected many aspects of the global society, including where they spend their holidays". Tourism is very sensitive to changes in safety and health. It is mentioned in the literature that tourism companies are often unprepared for crisis situations, and during an economic crisis, the approach of the tourism industry "in terms of crisis management depends on the level of economic development of the country, the availability of financial resources and capabilities government officials and industry employees" (Hu et al., 2021). The financially strong and the most efficient companies on the market survive a crisis. "In the last decade, much research has focused on the study of mechanisms for an efficient crisis and the post-crisis management of the tourism industry, both at the level of cities and regions" (Rutynsky \& Kushniruk, 2020).

"Currently, many front-line employees face an extremely high level of work-related stress and anxiety due to Covid-19" (Kang et al., 2021). The Covid-19 epidemic clearly poses a significant threat to the entire industry, to those employed in it and to those who wish to continue traveling (WTTC, 2020). The prolonged economic crisis is leading to financial difficulties among people who work or try to find a job. These problems "cause psychological distress and fear of losing a job among employees" (Khan et al., 2021). "The economical crisis has a significant impact on labour" (Shoss Mindy \&Tahira, 2012).

"Unprecedented global travel restrictions and the compulsoriness to stay at home cause the worst disruption of the global economy since World War II" (Gossling et al., 2020). "Travelers can carry microbes and their genetic material, they can be victims or carriers of viruses and travel restrictions, in particular urban isolation, would be the only strategy to combat epidemics in the future" (Chen \& Wilson, 2008). "Given the uncertainty 
caused by the Covid-19 epidemic, it is particularly important to adopt strategies to improve the safety of tourists in the post-pandemic context and to strengthen public confidence" (Chen et al., 2020).

Gursoy and Chi (2020) said that "almost all restaurants were asked to limit operations to take-out and restrictions on travel and residence orders issued by the authorities have led to a sharp decline in hotel occupancy and revenue". However, the reopening process has begun "slowly, and authorities have begun to relax restrictions, such as allowing restaurants to reopen at low capacity, with strict guidelines on social distancing, and gradually reducing restrictions on domestic and international travel" (Gursoy \& Chi, 2020).

"Preliminary findings from a longitudinal study by the editorial team of the Journal of Hospitality Marketing and Management suggest that reopening restaurants and easing travel restrictions will not bring customers back" (Gursoy \& Chi, 2020). In accordance with Gursoy (2020), "a large proportion of the customers $(50 \%)$ are not willing to dine at a restaurant immediately". The same goes for hotel accommodation. "Most of the customers are not willing to travel to a destination and to stay at a hotel anytime soon" (Gursoy \& Chi, 2020).

Perceived unemployment is a susceptible issue for employees. "If employees perceive that other organizations are firing their employees because of the prevailing situation, they become even more sensitive" (Khan et al., 2021). A worker who perceives unemployment would think that it is "difficult and sometimes impossible to find a job with the established skills he has" (Giorgi et al., 2015). "Low-income families are more affected by this fear, leading to various mental health and health problems" (DeVries \& Wilkerson, 2003).

In terms of demand, the "crisis will bring a reduction in disposable income, with a consequent reduction in the ability of tourists to pay" (Baker et al., 2020). On the other hand, uncertainty due to the pandemics determined tourists to postpone the decision to purchase until the last minute. Travel contracts concluded months in advance have decreased due to the high risk of cancellation, "as this move towards last-minute acquisitions is determined by the uncertainty of the situation" (Toubes et al., 2021).

"Consumer demands and their buying behaviour have changed radically and, as a result, companies have had to innovate their marketing strategies in order to survive" (Toubest et al., 2021). The tourist voucher is used by some destinations as a new product to stimulate the consumption of local customers. "Tourist vouchers are based on discount voucher models for purchases in hotels and other tourist accommodation units, restaurants and the tourism industry in general, with the aim of revitalizing one of the sectors most affected by the crisis" (Rutynskyi \& Kushniruk, 2020).

The stress at work

Because "workplace stress can lead to negative outcomes for employees, companies and organizations, workplace stress is an important factor in many academic and business studies" (Kang et al., 2021). Similar results have been "found in the hospitality industry, where stress at work decreases satisfaction with reception staff" (Kim et al., 2014). Studies investigating the regarded level of stress in tourism / hospitality of employees in the course of the Covid-19 pandemic remain limited.

Several studies refer to the number of researches conducted on the vaccine for Covid- 19 . However, "almost no study shows how employees suffered mentally because of this pandemic and employees were directly affected as the operation of the companies changed" (Khan et al., 2021). Supply chains have been broken due to unavailability of raw materials and travel restrictions. When "production and sales were adversely affected, organizations had to reduce 
costs, and therefore layoffs were one of the cost-cutting strategies" (Khan et al., 2021). The reduction in the "workforce involved employees who were laid off and created a sense of job uncertainty among the remaining employees" (Kim, 2003).

\section{RESEARCH MATERIALS AND METHODS}

The current study considers an epidemic that continues to unfold while this study is ongoing. The situation is unique and not much is known about this ongoing and growing disaster.

Qualitative and quantitative research methods vary in several ways, both in terms of data collection and explanation. While qualitative research focuses on the depth and quality of the data collected, quantitative research keeps the number and volume of data collected in the first place. In this paper we used a mix of research methods to investigate the impact of the Covid-19 pandemic on the hospitality sector and tourism employees. The research begins with a description of the contemporary crisis.

\subsection{Suppliers of touristic products}

"The services sector is severely affected by the Covid-19 pandemic, especially the hospitality industry, based on the accommodation, food and beverage segments" (Khan et al, 2021). The authors pointed out that "one way to control the spread of Covid-19 was blocking, being the main reason for the cancellation of economic activities". They said that "the hospitality industry was also affected by this, as domestic and international flights were stopped and there was no tourism, business travel, meetings and no flight crew to stay at airport hotels". In addition, "hotel operations (restaurants, conferences, seminars and banquets) have also been restricted, severely affecting economic and financial performance" (Khan et al., 2021).

Person-Fitcher and Liu (2021) said that "before the crisis, compared to operational risks, companies in tourism supply chains were interconnected in a complex model which led from one type of risk to another". In addition, in this crisis, multiple skills are considered a potential solution to reduce layoffs and retain employees for a long time. "This reflects the need for managers to recognize the importance of employees who have more jobs and who want to be full-time in the hotel and tourism industry" (Persson-Fitcher \& Liu, 2021). Kaushal and Srivastava (2021) stated that tourism service providers conducting "multi-skilled training for their employees before the crisis will reduce the corporate risk of losing a large number of employees" and the pressure of unemployment on employees during a crisis.

During the crisis, first of all, from mid-March 2020, operators lost much of their revenue, which made people worried about their financial stability and their ability to restore services. "Many tour operators may require direct or indirect government support" (Persson-Fitcher \& Liu, 2021). Managers in the hospitality industry should consider "wearing mandatory masks until a sustained solution is obtained, for example, the most considered solution in addition to the Covid-19 vaccine" (Kaushal \& Srivastava, 2021).

In a similar vein, Gössling and contributors (2020) demonstrate that "a regional reset is equally likely to strengthen selfish regionalism based on pre-existing power dynamics and growth-oriented development and to lead to regional reorientation towards sustainable practices". They also describe how the potential of the current transformational momentum is likely "to be removed in many regions, as governments pursue urgent job growth to 
alleviate rising unemployment". Hall, Scott and Gössling conclude with a classical expression: The changes brought to tourism as a "result of Covid-19 will be unequal in space and time, so that, although it is possible to see a new regionalism, it will probably be a mosaic of old and new approaches to tourism" (Brouder et al., 2020).

\subsection{Aspects of the financial crisis in the hospitality sector}

The most recent WTTC records (2021) show:

- "The travel and tourism sector suffered a loss of almost USD 4.5 trillion, reaching USD 4. 7 trillion in 2020" (WTTC, 2021);

- "The contribution to GDP decreased by $49.1 \%$ compared to 2019 , compared to a decrease of 3.7\% of the GDP of the global economy in 2020" (WTTC, 2021);

- In 2019, the travel and tourism sector accounted for $10.4 \%$ of global GDP, falling to 5 . $5 \%$ due to ongoing mobility restrictions;

- "In 2020, 62 million jobs were lost, representing a decrease of $18.5 \%$, leaving only 272 million employees in the entire sector globally, compared to 334 million in 2019";

- "Domestic visitors expenses decreased by 45\%, while international visitors expenses decreased by $64.9 \%$, without precedent" (WTTC, 2021).

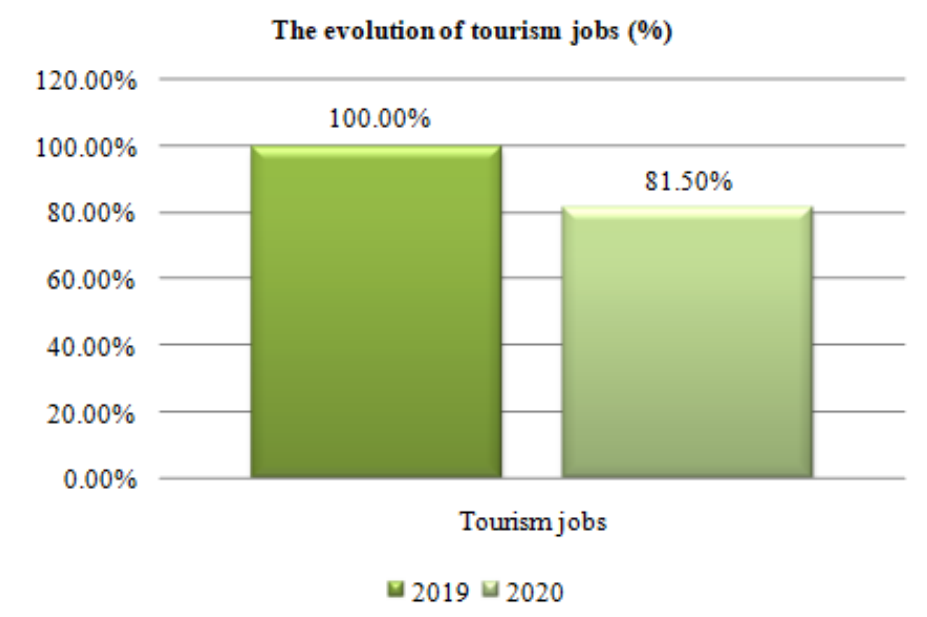

Fig. 1 The evolution of the contribution of tourism to GDP and jobs in 2020 Source: World Tourism Organisation

According to UNWTO (2021), "in 2020, 62 million jobs were lost, representing a percentage of $18.5 \%$ less than in $2019 "$.

Given that many companies and employees in the tourism sector have lost or will lose their jobs due to the Covid-19 pandemic, these companies have worked together to provide financial support to these employees by launching emergency funds, as well as partnerships for temporary jobs. For example, Accor has launched its All Heartist fund, allocating 70 million euros to help affected employees and partners. 


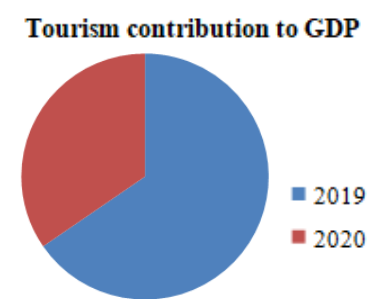

Fig. 2 The tourism contribution to GDP in 2020, compared to 2019 (\%) Source: World Tourism Organisation

From the graph above it can be seen that there has been a decrease in the tourism contribution to GDP in 2020 compared to 2019 due to the COVID-19 pandemic. "In 2019 , the tourism sector contributed $10.4 \%$ to global GDP, falling to $5.5 \%$ due to ongoing restrictions on mobility" (WTTC, 2020).

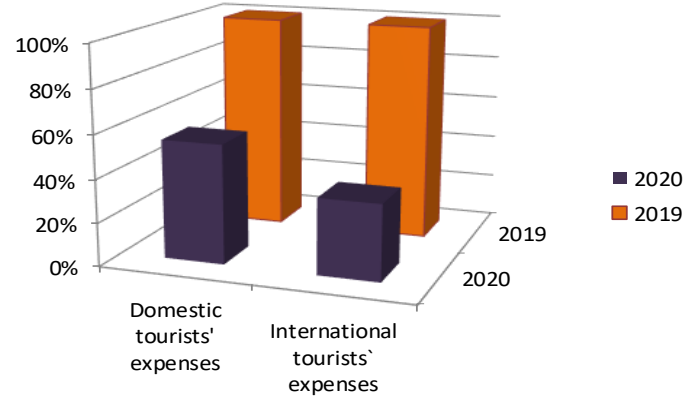

Fig. 3 The evolution of tourists' spending in 2020, compared to 2019 (\%) Source: World Tourism Organisation

From this chart it is easy to see that there were decreases in international tourists` expenses in 2020 compared to 2019. "Expenditure of domestic visitors fell by $45 \%$, while expenses by international tourists fell by $64.9 \%$, unprecedented" (WTTC, 2020).

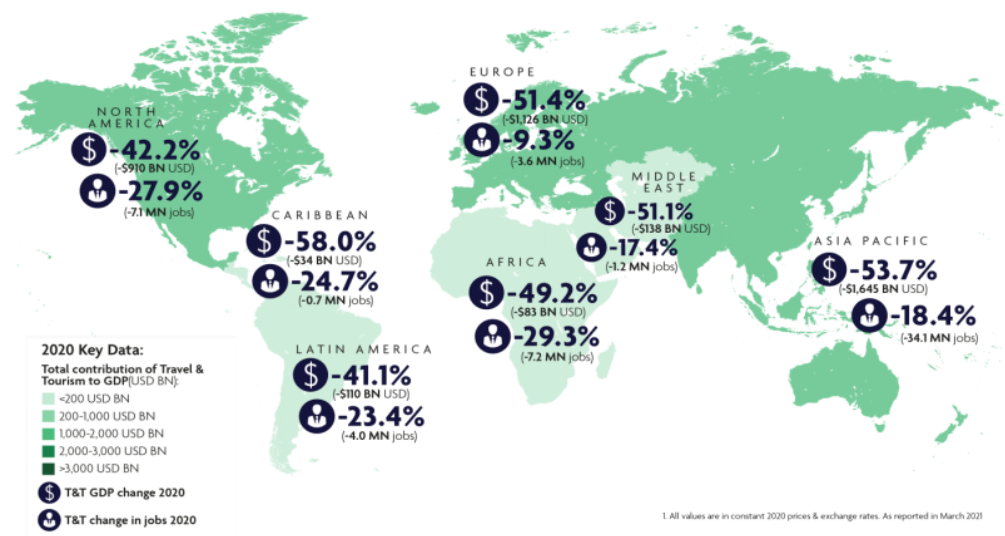

Fig. 4 Changes in 2020 regarding the tourism contribution to GDP and jobs in tourism. Source: EIR2020-Infographic-Map-Regional. png $(3509 \times 1923)$ (wttc. org) 
Globally, the Asia-Pacific region recorded the largest decline in the tourism contribution to GDP in 2020 compared to 2019, with a loss of $\$ 1.645$ billion and a reduction of 34.1 million jobs in tourism. In Europe, the tourism contribution to GDP registered a downward trend in 2020 and a decrease of 3.6 million in jobs in tourism in 2020, compared to 2019.

\section{CONCLUSIONS}

The global crisis of the Covid-19 pandemic has triggered an unprecedented decline in tourism business. Particularly vulnerable were the small and medium-sized companies that did not have strong financial resources and needed to sacrifice operating profits for the survival of businesses. Travel restrictions imposed by the COVID-19 pandemic have suppressed the tourism sector, a key player in the economy.

"While the hospitality industry is slowly recovering, the crisis caused by Covid-19 continues to have a profound impact on the way businesses in the hospitality sector operate" (Gursoy \& Chi, 2020). "These enterprises are expected to make substantial changes to their business operations in the context of the Covid-19 pandemic to ensure the health and safety of employees and customers" (Gössling et al., 2020). "The extended assumptions for 2021-2024 indicate a return in the second half of 2021" (WHO, 2021)

Almost all foreign experts anticipate a continuing crisis in the tourism and hospitality sector until 2023 or even 2024 and a growth in the cost of long-term travel services. The crisis in the tourism sector has led to "a 50\% drop in revenue for hotels and restaurants, a $70 \%$ drop for tour operators and agencies and a $90 \%$ drop for cruise operators and airlines" (ec. europa. eu), as the tourist retail received the main pelt. Travel agencies also had great opportunities to adapt to changing business strategies, one of which was the deep digitalization of the industry. "The use of digital technology in the context of the pandemic has thus fulfilled a social function, allowing both employees and customers not to feel isolated from the outside world" (Sheresheva et al., 2021).

Tourist movements may be limited to those who are immune or not. For the relaunch of tourism, most countries in the world accept tourists who have been vaccinated and present proof of vaccination, those who are tested and present a negative result of the PCR test or those who have been naturally immunized and they have already gone through the disease.

It is desired to return to normal as soon as possible, so that workers in the hospitality industry can feed their families and reduce the unemployment rate in their case. Adaptation is on everyone s mind, as is survival. Changes in strategy and policy will have to wait until operational adjustments are made. Everything that is happening now is experimental.

The important questions of the value of tourism will most likely dominate the tourism industry discourse in the future, as the consensus as to what tourism post COVID-19 will look like will still be up for discussion for some time to come.

Given the evolving nature of the situation, it is too early to estimate the impact of the COVID-19 on the hospitality industry and tourism employees.

Future research directions:

1. Continuing the research carried out on the impact of the COVID-19 pandemic on the hotel industry and tourism workers.

2. Widening the research horizon in order to diversify the chosen topic from a spatiotemporal point of view (for example, conducting similar research, but referring to a specific country). 
Acknowledgement: This work was supported by the grant POCU380/6/13/123990, co-financed by the European Social Fund within the Sectorial Operational Program Human Capital 2014 - 2020.

\section{REFERENCES}

Ahorsu, D.K., Lin, C.-Y., Imani, V., Saffari, M., Griffiths, M., \& Pakpour, A. H. (2020). The Fear of COVID19 Scale: Development and Initial Validation. International Journal of Mental Health and Addiction. 1-9. https://doi.org/10.1007/s11469-020-00270-8

Bai, Y., Yao, L., Wei, T., Tian, F., Jin, D.-Y., Chen, L., \& Wang, M. (2020). Presumed asymptomatic carrier transmission of COVID-19. JAMA, 323(14), 1406. https://doi.org/10.1001/jama.2020.2565

Baker, S. R., Bloom, N., Davis, S. J., \& Terry, S. J. (2020). Covid-induced economic uncertainty (No. w26983). National Bureau of Economic Research. https://doi.org/10.3386/w26983

Browne, A., Ahmad, S. S.-O., Beck, C. R., \& Nguyen-Van-Tam, J. S. (2016). The role of transport and transport centers in the spread of influenza and coronaviruses: A systematic analysis. Journal of travel medicine, 23(1), tav002. https://doi.org/10.1093/jtm/tav002

Brouder, P., Teoh, S., Salazar, N. B., Mostafanezhad, M., Pung M. J., Lapointe, D., Desbiolles, F. G., Haywood, M., Hall, M. C., \& Clausen H. B. (2020). Reflections and discussions: tourism matters in the new normal post COVID-19. Tourism Geographies, 22(3), 735-746. https://doi.org/10.1080/14616688.2020.1770325

Chen, H., Huang, X., \& Li, Z. (2020). A content analysis of Chinese news coverage on COVID-19 and tourism. Current Issues in Tourism, 1-8. https://doi.org/10.1080/13683500.2020.1763269

Chen, L. H., \& Wilson, M. E. (2008). The role of the traveler in emerging infections and magnitude of travel. Medical Clinics of North America, 92(6), 1409- 1432. https://dx.doi.org/10.1016\%2Fj.mcna.2008.07.005

Cristea, M., Noja, G. G., Ponea, S., \& Banaduc, I. (2020). Labor productivity in the complex interplay between health and well-being of order employees: a focus on the new European Union member states under the COVID-19 pandemic crisis. Economic and Social Development: Book of Proceedings, 69-78.

DeVries, M. W., \& Wilkerson, B., (2003). Stress, work and mental health: a global perspective. Acta neuropsychiatrica, 15(1), 44-53. https://doi.org/10.1034/j.1601-5215.2003.00017.x

European Parilament. COVID-19: EU support for the tourism sector

Firoiu, D., Ionescu, G.H., Bădîrcea, R., Vochița, L., \& Enescu, M. (2019). Sustainable Development of Mountain Hotels through the Implementation of International Management Standards: The Romanian Case. Sustainability, 11, 6487. https://doi.org/10.3390/su11226487

Giorgi, G., Shoss, M. K., \& Leon-Perez, J. M.. (2015). Going beyond workplace stressors: Economic crisis and perceived employability in relation to psychological distress and job dissatisfaction. International Journal of Stress Management, 22(2), 137. https://psycnet.apa.org/doi/10.1037/a0038900

Gruescu, R., Nanu, R. \& Vochița, L. (2009). Tourism and development in Romania - Human Resource management. People as critical resources in tourism, Academica Greifswald, Germany.

Gursoy, D., \& Chi, C. (2020). Effects of COVID-19 pandemic on hospitality industry: review of the current situations and a research agenda. Journal of Hospitality Marketing \& Management, 29(5), 527-529. https://doi.org/10.1080/19368623.2020.1788231

Gursoy, D., Chi, C. G. \& Chi, O. H. (2020). COVID-19 Study 2 Report: Restaurant and Hotel Industry: Restaurant and hotel customers' sentiment analysis. Would they come back? If they would, WHEN. No. 2. Report.

Gössling, S., Scott, D., \& Hall, C. M. (2020). Pandemics, tourism and global change: a rapid assessment of COVID-19. Journal of Sustainable Tourism, 29(1), 1-20. https://doi.org/10.1080/09669582.2020.1758708

Hu, H., Yang, Y., \& Zhang, J. (2021). Avoiding panic during pandemics: COVID-19 and tourism-related businesses. Tourism Management, 86(3) 104316. http://dx.doi.org/10.1016/j.tourman.2021.104316

Ionescu, G. H., Firoiu, D., Pirvu, R., \& Vilag, R. D. (2019). The impact of ESG factors on market value of companies from travel and tourism industry. Technological and Economic Development of Economy, 25(5), 820-849. https://doi.org/10.3846/tede.2019.10294

Kang, S.-E., Park, C., Lee, C.-K., \& Lee, S. (2021). The Stress-Induced Impact of COVID-19 on Tourism and Hospitality Workers. Sustainability 13(3), 1327. https://doi.org/10.3390/su13031327

Kaushal, V., \& Srivastava, S. (2021). Hospitality and tourism industry amid COVID-19 pandemic: Perspectives on challenges and learnings from India. International Journal of Hospitality Management, 92, 102707. https://doi.org/10.1016/j.ijhm.2020.102707

Kim, W. B. (2003). Economic crisis, downsizing and "layoff survivor's syndrome". Journal of Contemporary Asia, 33(4), 449-464

Kim, G., Ro, H.,. Hutchinson, J., \& Kwun, D. J. (2014). The Effect of Jay-customer Behaviors on Employee Job Stress and Job Satisfaction. International Journal of Hospitality \& Tourism Administration, 15(4), 394416. https://doi.org/10.1080/15256480.2014.961797 
Khan, K. I., Niazi, A., Nasir, A., Hussain, M., \& Khan, M. I. (2021). The Effect of COVID-19 on the Hospitality Industry: The Implication for Open Innovation. Journal of Open Innovation: Technology, Market, and Complexity, 7(1), 30. https://doi.org/10.3390/joitmc7010030

Nicola, M., Alsafi, Z., Sohrabi, C., Kerwan, A., Al-Jabir, A., Iosifidis, C., Agha, M., \& Agha, R. (2020). The socioeconomic implications of the coronavirus pandemic (COVID-19): A review. International journal of surgery, 78, 185-193. https://doi.org/10.1016/j.ijsu.2020.04.018

Pappa, S., Ntella, V., Giannakas, T., Giannakoulis, V.G., Papoutsi, E. \& Katsaounou, P. (2020). Prevalence of depression, anxiety, and insomnia among healthcare workers during the COVID-19 pandemic: A systematic review and meta-analysis. Brain, behavior, and immunity, 88, 901-907. https://doi.org/10.1016/ j.bbi.2020.05.026

Persson-Fischer, U., \& Liu, S. (2021). The Impact of a Global Crisis on Areas and Topics of Tourism Research. Sustainability 13(2), 906. https://doi.org/10.3390/su13020906

Rutynskyi, M., \& Kushniruk, H. (2020). The impact of quarantine due to COVID-19 pandemic on the tourism industry in Lviv (Ukraine). Problems and Perspectives in Management, 18(2), 194-205. http://dx.doi.org/ $10.21511 / \mathrm{ppm} .18(2) .2020 .17$

Sheresheva, M., Efremova, M., Valitova, L., Polukhina, A., \& Laptev, G. (2021). Russian Tourism Enterprises' Marketing Innovations to Meet the COVID Challenges. Sustainability 13(7), 3756. https://doi.org/10.3390/ su13073756

Shoss Mindy, K., \& Tahira, M. P. (2012). Multilevel Outcomes of Economic Stress: An Agenda for Future Research. In The Role of the Economic Crisis on Occupational Stress and Well Being, Pamela, L. P., Jonathon, R. B. H., Christopher, C. R., Eds., Emerald Group Publishing Limited: Bingley, UK, pp. 43-86.

Škare, M., Soriano, D. M., \& Porada-Rochon, M. (2021). Impact of COVID-19 on the travel and tourism industry. Technological Forecasting and Social Change, 163, 120469. https://doi.org/10.1016/j.techfore. 2020.120469

Tănasie, A., \& Fratoștițeanu, C. (2009). Tourism investments, growth and redistribution as tools for development. Academica Greifswald, Germany.

Tănasie, A. (2011). The Economic Crisis In Europe. Monetary Implications. Analele Universitătii din CraiovaSeria Ştiinţe Economice, 39, 1-6.

Toubes, D. R., Araújo Vila, N., \& Fraiz Brea, J. A. (2021). Changes in Consumption Patterns and Tourist: Promotion after the COVID-19 Pandemic. Journal of Theoretical and Applied Electronic Commerce Research, 16(5), 1332-1352. https://doi.org/10.3390/jtaer16050075

Yang, Y., Zhang, H., \& Chen, X. (2020). Coronavirus pandemic and tourism: Dynamic stochastic general equilibrium modeling of infectious disease outbreak. Annals of tourism research, 83, 102913. https://doi.org/10.1016/ j.annals.2020.102913

World Health Organization. WHO Coronavirus Disease (COVID-19) Dashboard. Available online: https://covid19.who.int/?gclid=CjwKCAjw8df2BRA3EiwAvfZWaLjXv9_ihvupSmNYxrKekgxU3ubtAKQ e1-q-JzVdd5LE_gqTddb6QhoCqhsQAvD_BwE

World Travel \& Tourism Council. Coronavirus Puts Up to 50 Million Travel and Tourism Jobs at Risk Says WTTC. Available online: https://wttc.org/News-Article/Coronavirus-puts-up-to-50-million-Travel-andTourism-jobs-at-risk-says-WTTC

World Travel \& Tourism Council. Travel \& Tourism Economic Impact | World Travel \& Tourism Council (WTTC)

\section{UTICAJ PANDEMIJE KOVID-19 NA RADNIKE U INDUSTRIJI UGOSTITELJSTVA I TURIZMA}

Trenutna pandemija koronavirusa (Covid-19) dovela je svet u jaku socio-ekonomsku krizu $i$ psihološki stres. Negativno je uticala na ekonomiju, ali sektor uskuga, a naročito ugostiteljstva je najviše pogođen njome. Ovaj rad istražuje kako ovaj virus utiče na organizaciono samopouzdanje, zadovoljstvo poslom, i povećani osećaj nesigurnosti zaposlenih i strah od gubitka posla. Izvršili smo komparativnu analizu glavnih indikatora u turizmu u 2020. godini u poređenju sa istim periodom u 2019, uzimajući u obzir međunarodno zabeležene podatke. Isto tako, istraživanje ima za cilj da utverdi koliko je sektor ugostiteljstva pogođen krizom koju je izazvala pandemija Kovid19. Rezulktati ukazuju da percipirana nesigurnost posla interpolira strah od ekonomske krize.

Ključne reči: Kovid-19 strah, percipirana nesigurnost posla, industrija ugostiteljstva, nezaposlenost 